\title{
PEMAHAMAN PENDIDIK DAN TENAGA KEPENDIDIKAN TENTANG PENDIDIKAN UMUM DENGAN KEKHASAN AGAMA ISLAM DI MAN 3 MALANG
}

\author{
Moch Tolchah \\ Universitas Islam Negeri Sunan Ampel Surabaya, Indonesia \\ E-mail: mochtolchah@yahoo.com
}

\begin{abstract}
Discourses on Islamic school curriculum can be divided into theoretical and practical levels. In this paper, the practical level of the curriculum is examined in terms of its philosophical meaning within teachers, the translation of the philosophical view into school curriculum, and what strategy is being used to sharpen the curriculum messages. This article discusses the understanding of the school teachers and administrators towards the specific religious characteristics of public education at Madrasah Aliyah Negeri (MAN) 3 Malang. From the field research, this article finds three important results. First, the educators in MAN 3 Malang perceived their institution as the agent of amalgamation between Pesantren tradition and secular education to uphold excellences in academic and non-academic areas. Second, in order to materialize such philosophical thought, the educators developed and implemented particular schemata. Third, in order to strengthen Islamic characteristics through curriculum development, the school applied the strategy of religious activity, direct monitoring and evaluation, educative activity designs, and implementing school's vision through strategic platforms.
\end{abstract}

Keywords: School curriculum; public education with religious characteristics; strategic platforms.

\section{Pendahuluan}

Pendidikan merupakan kunci kemajuan. Semakin baik kualitas pendidikan yang diselenggarakan oleh suatu masyarakat, maka akan diikuti dengan semakin baiknya kualitas masyarakat tersebut. Sehubungan dengan ini Fazlur Rahman menyatakan bahwa setiap reformasi dan pembaruan dalam Islam harus dimulai dengan 
pendidikan. ${ }^{1}$ Inilah mengapa kajian pengembangan pendidikan Islam tiada henti untuk didiskusikan oleh para ahli dan pemerhati Pendidikan Islam itu sendiri.

Senada dengan pemikiran di atas, Khursid Ahmad menyatakan of all the problem that confront the Muslim world today, the educational problem is the most challenging. The future of the Muslim world will depend upon the way it responds to this challenge. ${ }^{2}$ Dari pernyataan di atas menyiratkan bagaimana umat Muslim menyikapi tantangan dalam bidang pendidikan menjadi penentu dari masa depan masyarakat Muslim itu sendiri. Dalam konteks keindonesiaan, pernyataan tersebut menunjukkan bahwa masa depan Islam di Indonesia juga bergantung kepada bagaimana cara umat Islam merespons dan memecahkan pelbagai masalah pendidikan yang berkembang di Indonesia, terutama dalam konteks pengembangan sistem pendidikan Islam di masa depan.

Pendidikan Islam di Indonesia juga sudah berlangsung dan berkembang sejak sebelum Indonesia merdeka hingga sekarang dan yang akan datang. Hal ini dapat dilihat dari fenomena pertumbuhan dan perkembangan program dan praktik penyelenggaraan pendidikan Islam yang dilaksanakan di Nusantara. Fenomena ini menunjukkan adanya pemikiran tentang pengembangan pendidikan Islam di Indonesia dalam berbagai jenis dan bentuknya. Adanya kegiatan dan sistem pendidikan Islam yang memiliki ciri-ciri tertentu, menurut 'Ubûd ${ }^{3}$ dan Langgulung', menggambarkan adanya teori-teori, ilmu dan/atau pemikiran pendidikan Islam.

Menurut Arief Furchan $^{5}$, jauh sebelum Belanda menjajah Indonesia, lembaga pendidikan Islam yang ada adalah pesantren yang memusatkan kegiatannya untuk ilmu agama. Ketika pemerintah Hindia-Belanda membutuhkan tenaga terampil untuk urusan

1 Fazlur Rahman, Islam, terj. Ahsin Muhammad (Bandung: Pustaka, Cet. Ke-3, 1997), 260.

2 Faisal Ismail, Paradigma Kebudayaan Islam: Studi Kritis dan Refleksi Historis (Yogyakarta: Titian Ilahi Press, 1996), 31.

${ }^{3}$ Ubud menyatakan $W$ a lays mumkin an takûn hunâk tarbîyah Islâmîyah wa niżâm ta'lim Islâmî, dîn an takîn hunâk nazarîyah tarbawîyah Islâmîyah aw fiker tarbawî Islamî. Baca 'Ubûd Abd al-Ghâni, Fî al-Tarbîyah al-Islâmîyah (Mesir: Dâr al-Fikr al-'Arabî, 1977), 119.

4 Hasan Langgulung, Asas-asas Pendidikan Islam (Jakarta: Pustaka Al-Husna, 1988), 118-119.

5 Arief Furchan, "Pemberdayaan Madrasah dan Tantangan Globalisasi", makalah disajikan dalam Seminar Sehari di Pondok Pesantren Zainul Hasan Genggong, 25 April 1999. 
administrasi pemerintahannya, maka diperkenalkanlah jenis pendidikan yang beroritentasi pekerjaan. Proklamasi kemerdekaan Republik Indonesia pada tahun 1945 ternyata melahirkan kebutuhan akan banyak tenaga terdidik dan terampil untuk menangani administrasi pemerintahan dan juga untuk membangun negara dan bangsa. Untuk itu, pemerintah lalu memperluas pendidikan model Barat yang dikenal dengan sekolah umum itu. Untuk mengimbangi kemajuan zaman itu, di kalangan santri timbul keinginan untuk memodernisasi lembaga pendidikan mereka dengan mendirikan madrasah. Dengan demikian, madrasah adalah perkembangan modern dari pesantren.

Perbedaan utama madrasah dengan pesantren terletak pada sistem pendidikannya. Madrasah menganut sistem pendidikan formal (dengan kurikulum nasional, pemberian pelajaran dan ujian yang terjadwal, bangku dan papan tulis seperti umumnya sekolah model Barat) sementara pesantren menganut sistem non-formal (dengan kurikulum yang sangat bersifat lokal, pemberian pelajaran yang tidak seragam, sering tanpa ujian untuk mengukur keberhasilan belajar siswa, dan seterusnya). Ciri lain yang umumnya membedakan keduanya adalah adanya mata pelajaran umum di madrasah. Penambahan mata pelajaran umum pada kurikulum madrasah ini tidak berjalan seketika. Pada awalnya, kurikulum madrasah masih $100 \%$ berisi pelajaran agama-tanpa ada pelajaran umumsebagaimana pesantren. Hanya saja yang membedakan madrasah dengan pesantren adalah perangkat keras, perencanaan, dan evaluasi dengan model pendidikan Barat. Lulusan madrasah pada masa itu tidak dapat melanjutkan pelajarannya ke sekolah umum yang lebih tinggi, bahkan juga tidak dapat pindah ke sekolah umum yang sejenjang karena kurikulumnya berbeda. Orang tua yang ingin mendidik anaknya dalam ilmu agama dan ilmu umum harus menyekolahkan anaknya di dua tempat, di sekolah umum dan di madrasah.

Pada tahun 1975, terdapat Surat Keputusan Bersama tiga Menteri (Menteri Agama, Menteri Pendidikan dan Kebudayaan, dan Menteri Dalam Negeri) yang menetapkan bahwa lulusan madrasah dianggap setara dengan lulusan sekolah umum, sehingga dapat melanjutkan ke sekolah umum yang lebih tinggi dan boleh berpindah ke sekolah umum yang sama jenjangnya. Kompensasi dari kesetaraan itu adalah $70 \%$ dari kurikulum madrasah harus berisi mata pelajaran umum. 
Selanjutnya, berdasarkan kurikulum madrasah 1994, kurikulum madrasah harus memuat 100\% kurikulum sekolah umum. Dalam undang-undang nomor 2 tahun 1989 tentang Sistem Pendidikan Nasional, madrasah dikategorikan sebagai Sekolah Umum yang berciri khas agama Islam. ${ }^{6}$

Undang-Undang RI Nomor 20 Tahun 2003 tentang Sistem Pendidikan Nasional memposisikan madrasah sama atau sederajat dengan lembaga sekolah. Tidak ada perbedaan apapun antara keduanya, minimal secara legal formalistik. Menurut UU tersebut, jenis pendidikan umum jenjang pendidikan dasar adalah berbentuk SD dan MI atau bentuk lain yang sederajat, serta SMP dan M'Ts atau bentuk lain yang sederajat, sedangkan pendidikan menengah berbentuk SMA, MA, SMK dan MAK, atau bentuk lain yang sederajat (bab VI pasal 17 dan 18). Diktum pada kedua pasal ini menunjukkan bahwa posisi madrasah adalah sama atau sederajat dengan sekolah, yaitu termasuk ke dalam jenis pendidikan umum. Hal ini berbeda dengan undang-undang sebelumnya (UU RI No. 2/1989 tentang Sisdiknas) yang menyatakan bahwa madrasah adalah sekolah umum berciri khas agama Islam.

Posisi madrasah dalam Sistem Pendidikan Nasional saat ini (sebagaimana UU RI No. 20 tahun 2003) bisa jadi akan memiliki implikasi yang sangat serius, terutama berkaitan dengan capaian idealisme yang ingin diraih oleh madrasah atas dasar visi dan misinya sebagai lembaga pendidikan Islam. Dikatakan demikian, karena sejak mulai dikenal di kalangan masyarakat Muslim Indonesia, madrasah tumbuh sebagai lembaga pendidikan dengan karakteristik yang membedakan dirinya dari sistem sekolah. Secara spesifik madrasah dibangun oleh individu atau masyarakat Muslim sebagai wujud kesadaran keberagamaan masyarakat Muslim terhadap pentingnya pemahaman sekaligus pelestarian ajaran agama (tafaqquh fì al-dîn) kepada anak-anak generasi penerus.

Dalam ranah praktis, karakteristik tersebut lebih dikenal dengan jati diri madrasah sebagai lembaga pendidikan Islam yang mencakup jati diri Islam dan umat Islam. ${ }^{7}$ Masyarakat Muslim berupaya

${ }^{6}$ Ibid.

7 Sebagai lembaga Pendidikan Islam, madrasah melaksanakan kegiatan pendidikan Islam, yakni "upaya normatif untuk membantu seseorang atau sekelompok orang (siswa) dalam mengembangkan pandangan hidup Islami (bagaimana akan menjalani dan memanfaatkan hidup dan kehidupan sesuai dengan ajaran dan nilai-nilai Islam), yang diwujudkan dalam sikap hidup, dan dimanifestasikan dalam keterampilan 
melaksanakan pendidikan yang sejalan dengan visi dan misi religiositasnya. Dalam hal ini, Islam ditempatkan sebagai sumber nilai yang akan selalu diwujudkan dalam seluruh kegiatan pendidikan di madrasah.

Madrasah sebagai bagian dari lembaga pendidikan Islam, mewarisi berbagai ciri dan kekhasan di atas secara sempurna, baik secara tipikal maupun dari aspek substansi muatannya dan bahkan budaya yang dikembangkan oleh masyarakat yang membesarkannya. Tidak berlebihan jika dikatakan bahwa historical background madrasah sejak awal mula keberadaannya hingga saat ini berada pada alur yang konsisten.

Asumsi tersebut dibangun dengan penguatan hasil penelitian Puslitbang Pendidikan Agama dan Keagamaan, yang menegaskan bahwa upaya peningkatan mutu pendidikan madrasah yang diharapkan oleh stakeholders madrasah (guru, pegawai, dan masyarakat selaku responden penelitian) harus berlandaskan kepada nilai-nilai yang menjadi panutan seluruh masyarakat pendukung madrasah itu sendiri. ${ }^{8}$ Selain itu, animo masyarakat terhadap MAK (Madrasah Aliyah Keagamaan) masih cukup besar ditandai dengan fakta bahwa siswa, guru, orang tua siswa dan masyarakat masih memiliki semangat dan minat yang cukup besar untuk mempertahankan MAK. Ini dibuktikan dengan jumlah pendaftar MAK cenderung stabil bahkan meningkat. Artinya, tingginya apresiasi masyarakat terhadap MAK (dulu MAPK) menunjukkan bahwa penyelenggaraan pendidikan madrasah dengan kekhasan tafaqquh fì al-dîn, secara jelas masih menjadi harapan besar masyarakat. ${ }^{9}$ Penelitian dengan topik sejenis juga dilakukan pada tahun 2007 dan menunjukkan bahwa integrasi madrasah ke dalam sistem pendidikan nasional belum tentu memberikan dampak positif bagi madrasah dan umat Islam. Integrasi madrasah seharusnya bermanfaat bagi peningkatan kualitas madrasah, bukan sebaliknya, menghilangkan jati diri madrasah sebagai lembaga pendidikan Islam. ${ }^{10}$

hidup sehari-hari”. Lihat Muhaimin, Pengembangan Kurikulum Pendidikan Agama Islam di Sekolah: Madrasah dan Perguruan Tinggi (Jakarta: PT RajaGrafindo Persada, Cet. Ke4, 2010), 202.

8 Puslitbang Pendidikan Agama dan Keagamaan, Manajemen Madrasab (Jakarta: Badan Litbang dan Diklat Kementerian Agama RI, 2006).

${ }^{9}$ Ibid.

10 Puslitbang Pendidikan Agama dan Keagamaan, Respons Masyarakat terhadap Reposisi Madrasah sebagai Pendidikan Umum Menurut UU Nomor 20 Tahun 2003 
Tiga hasil penelitian di atas memberikan kesimpulan bahwa peningkatan mutu pendidikan madrasah harus dibarengi dengan selalu menjaga agar mutu pendidikan agamanya tetap unggul. Masyarakat memandang madrasah harus sejajar dengan sekolah umum, tapi tidak berarti mengurangi apalagi menghilangkan ciri khas keagamaannya. Reposisi dengan tetap mempertahankan penguasaan ilmu-ilmu agama justru memberikan nilai tambah bagi peningkatan kualitas pendidikan madrasah, sehingga tujuan menciptakan insan yang memiliki keunggulan keagamaan dan ilmu pengetahuan dan teknologi bisa tercapai.

Di dalam UU RI No. 20/2003 tentang Sisdiknas masih belum tegas dinyatakan bahwa madrasah merupakan sekolah umum yang berciri khas agama Islam. Tetapi, menurut Peraturan Pemerintah RI Nomor 17 tahun 2010 tentang Pengelolaan dan Penyelenggaraan Pendidikan, pada pasal 1 ayat (9), (11) dan (14), dinyatakan bahwa madrasah adalah salah satu bentuk satuan pendidikan formal dalam binaan Menteri Agama yang menyelenggarakan pendidikan umum dengan kekhasan agama Islam pada jenjang pendidikan dasar dan menengah. Hal ini menggarisbawahi perlunya madrasah memahami makna substantif dan praktik dari pendidikan umum dengan kekhasan agama Islam yang membedakannya dengan sistem sekolah, untuk selanjutnya diimplementasikan dalam pengembangan kurikulum di madrasah.

Jika madrasah dinyatakan sebagai pendidikan umum dengan kekhasan agama Islam, maka para pendidik dan tenaga kependidikan madrasah harus memiliki pemahaman komprehensif mengenai makna substantif dan praktiknya yang sekaligus diimplementasikan dalam pengembangan kurikulum madrasah. Untuk itulah penulis melakukan penelitian terkait "Pengembangan Kurikulum Pendidikan Islam (Studi Pemahaman Pendidik dan Tenaga Kependidikan tentang Pendidikan Umum dengan Kekhasan Agama Islam di MAN 3 Malang)".

Hasil survei pendahuluan menunjukkan MAN 3 Malang merupakan salah satu dari lima madrasah model di Jawa Timur dan juga merupakan salah satu madrasah terpadu dari delapan madrasah terpadu se-Indonesia. ${ }^{11}$ Madrasah ini merupakan madrasah yang membawa asas Islami, Unggul, Populis dan bertujuan untuk

tentang Sistem Pendidikan Nasional (Jakarta: Badan Litbang dan Diklat Kementerian Agama RI, 2007).

11 Abd. Djalil, Wawancara, Malang, 17-19 Juni 2010. 
membentuk jiwa muda Indonesia yang Islami dan dinamis. Karena itu, MAN 3 Malang berusaha menyeimbangkan kecerdasan otak dan hati.

Ditinjau dari kelembagaan, MAN 3 Malang mempunyai tenaga akademik yang handal dalam pemikiran, memiliki manajemen yang kokoh yang mampu menggerakkan seluruh potensi untuk mengembangkan kreativitas civitas akademika MAN 3 Malang, serta memiliki kemampuan antisipatif masa depan dan proaktif. Selain itu MAN 3 Malang memiliki pimpinan yang mampu mengakomodasikan seluruh potensi yang dimiliki menjadi kekuatan penggerak lembaga secara menyeluruh.

Berbagai harapan mengenai profil guru, pegawai, siswa dan lulusan tersebut di atas pada dasarnya merupakan bagian dari perwujudan makna substansial madrasah sebagai pendidikan umum dengan kekhasan agama Islam. Namun demikian, apakah harapanharapan tersebut benar-benar dipahami oleh warga MAN 3 Malang, terutama oleh para pendidik (guru) dan tenaga kependidikan lainnya? Bagaimana praktiknya dalam pengembangan kurikulum? Upaya apa saja yang dilakukan untuk penguatan kekhasan agama Islam? Pertanyaan-pertanyaan tersebut dikupas dalam tulisan ini yang dibagi dalam tiga bagian sub-kajian, yaitu kajian diperlukan penelitian yang komprehensif, sehingga ditemukan model pengembangan pendidikan umum dengan kekhasan agama Islam untuk selanjutnya dapat dikembangkan ke madrasah lainnya.

\section{Persepsi Madrasah sebagai Sekolah Umum Berwawasan Agama}

Terkait dengan peran guru sebagai pendidik yang merancang segala proses yang terjadi di Madrasah, maka seorang guru idealnya memiliki pemahaman yang baik tentang makna substantif madrasah sebagai sebuah lembaga. Pemahaman terhadap makna substantif dapat dideskripsikan berdasarkan beberapa indikator sebagai berikut: pengertian, ciri-ciri, nilai yang dikembangkan di madrasah, tujuan penanaman nilai dan kegunaaannya.

Untuk mengetahui makna substantif Madrasah sebagai sebuah lembaga pendidikan dapat diawali dari pengertian kata madrasah secara harfiah. Kata madrasah adalah ism makân dari kata daras yadrus dars, yang berarti terhapus, hilang bekasnya, menghapus, menjadikan usang, melatih, dan mempelajari. Dilihat dari pengertian tersebut Muhaimin berpendapat bahwa madrasah berarti tempat untuk mencerdaskan para peserta didik, menghilangkan ketidaktahuan atau 
memberantas kebodohan mereka, serta melatih keterampilan mereka sesuai dengan bakat, minat, dan kemampuannya. ${ }^{12}$

Dalam konteks MAN 3 Malang, setiap guru memiliki pemahaman yang berbeda tentang madrasah. meski demikian dapat diambil sebuah kesimpulan bahwa pengertian madrasah sebagai sekolah umum dengan kekhasan agama islam adalah lembaga pendidikan yang memberikan nilai moral dan keagamaan yang lebih banyak baik melalui materi yang disampaikan (materi agama lebih banyak dan disajikan dalam mata pelajaran terpisah), pendekatan yang digunakan, penciptaan suasana dan lingkungan yang Islami, karakter pondok pesantren dan budaya Islami yang dikembangkan.

Pada dasarnya ada dua faktor yang melatari lahirnya madrasah di Indonesia. Pertama, pendidikan tradisional (surau, masjid, dan pesantren) dianggap kurang sistematis dan kurang memberikan kemampuan pragmatis yang memadai. Kedua, adanya perkembangan sekolah-sekolah Belanda di kalangan masyarakat cenderung meluas dan membawa watak sekularisme, sehingga harus diimbangi dengan adanya sistem pendidikan Islam yang memiliki model dan organisasi yang lebih teratur dan terencana. ${ }^{13}$ Dengan demikian, kehadiran madrasah merupakan format pendidikan yang mengamalgamasikan antara orientasi keahlian pada pendidikan modern dengan internalisasi nilai kebudayaan yang bersumber dari agama.

Selain melalui pengertian, untuk mengetahui makna substantif madrasah, ciri khas yang ada pada sebuah lembaga pendidikan juga mampu mengilustrasikan substansinya. Ciri madrasah sebagai lembaga pendidikan dengan kekhasan Agama Islam dapat didasarkan pada Keputusan Menteri Agama RI, Nomor 302 Tahun 1993 bahwa madrasah sebagai sekolah umum dengan kekhasan Agama Islam memiliki ciri berikut. Pertama, pemberian mata pelajaran Pendidikan Agama Islam, yang meliputi: al-Qur'ân dan al-Ḥadîth, Aqidah-Akhlaq, Fiqh, dan Sejarah Kebudayaan Islam. Kedua, penciptaan suasana kegamaan, antara lain melalui: suasana kehidupan madrasah yang agamis, adanya sarana ibadah, penggunaan pendekatan yang agamis dalam penyajian mata pelajaran yang memungkinkan, dan pengadaan

\footnotetext{
${ }^{12}$ Muhaimin, Pengembangan Kurikulum, 183-184.

13 Masduki, Seri Informasi Pendidikan Islam Indonesia No. 6: Menelusuri Pertumbuban Madrasab di Indonesia (Jakarta: Direktorat Jendral Kelembagaan Agama Islam, Depag RI, 2001).
} 
guru yang memiliki kualifikasi keagamaan seperti beragama Islam dan berakhlak mulia. ${ }^{14}$

Hal ini sesuai dengan hasil temuan penelitian bahwa pemahaman guru makna madrasah jika dianalisis lebih lanjut melalui cirinya bisa dikelompokkan menjadi tiga hal pokok. Pertama, materi keagamaan yang diberikan kepada siswa lebih banyak baik dari segi macam bidang studi (al-Qur'ân-al-Hadith, Aqidah Akhlaq, Fiqh, dan Sejarah Kebudayaan Islam, maupun dari segi jumlah jam tatap muka di kelas. Kedua, suasana dan tradisi yang dikembangkan di madrasah. Hal ini di Madrasah sebelum memulai pelajaran senantiasa diawali dengan membaca al-Qur'ân, membiasakan amalan-amalan keagamaan misalnya puasa sunnah, salat Duha, dan salat Zuhur berjemaah. Selain itu pola pergaulan di madrasah cenderung ditata sedemikian rupa agar tidak bertentangan dengan nilai-nilai keagamaan. Ketiga, madrasah menjadikan masjid sebagai bagian yang tidak terpisahkan dari sebuah proses pembelajaran untuk mewujudkan lulusan sesuai dengan profil yang diharapkan.

Madrasah sebagai lembaga pendidikan yang memiliki ciri khas yang berbeda dengan lembaga pendidikan lainnya karena pada dasarnya madrasah pada mulanya merupakan lembaga pendidikan tradisional yang dikenal dengan nama madrasah diniyah yang kurikulumnya terbatas pada pengajaran Bahasa dan Sastra Arab, ilmuilmu Tafsir, Hadith, Fiqh, Ushul Fiqh, Tasawuf, dan cabangcabangnya. Namun tidak seperti pesantren yang sangat fleksibel dan tidak memiliki sistem kelas dan tingkatan yang formal, sistem madrasah mengaplikasikan sistem kelas dan jenjang-jenjang pendidikan dan menengah seperti pada sekolah-sekolah formal yang lain.

Berdasarkan temuan pada objek penelitian, ciri khas madrasah selain hal tersebut dapat dilihat dari visi misinya, budaya keagamaannya, dan karakteristik keilmuannya. Visi dan misi madrasah objek penelitian adalah terwujudnya madrasah model sebagai pusat keunggulan dan rujukan dalam kualitas akademik dan non-akademik serta akhlaq karimah. Visi tersebut diuraikan dalam misi membangun budaya madrasah yang membelajarkan dan mendorong semangat keunggulan, mengembangkan SDM madrasah yang kompeten, menyelenggarakan pendidikan yang menghasilkan lulusan berkualitas akademik dan non-akademik serta akhlaq karimah, mengembangkan

${ }^{14}$ Keputusan Menteri Agama RI, Nomor 302 Tahun 1993, 12. 
sistem dan manajemen madrasah yang berbasis penjaminan mutu, menciptakan dan memelihara lingkungan yang sehat, kondusif, dan harmonis, meningkatkan peran serta stakeholders dalam pengembangan madrasah, mewujudkan madrasah yang berorientasi pada standar internasional serta ada beberapa nilai yang ingin dikembangkan di madrasah yakni: keindahan, ketakwaan, kebenaran, kebaikan, kecerdasan, kebersamaan, dan keindahan.

Sedangkan religious culture yang dikembangkan di madrasah dapat dilihat dari adanya beberapa kegiatan praktis keagamaan yang dilakukans ecara rutin dan terjadwal, seperti mengaji sebelum kegiatan belajar mengajar dimulai, salat Duha berjemaah, salat Zuhur berjemaah, pembiasaan puasa senin kamis bagi siswa, guru dan karyawan, adanya kaligrafi di lingkungan madrasah dan kelas, serta tulisan yang berisi anjuran untuk melaksanakan ajaran Islam.

Ciri khas keilmuan pada objek penelitian telah menempatkan keagamaan dan keilmuan umum pada sebuat kontinum yang saling melengkapi. Di MAN 3 Malang, setiap guru melakukan integrasi materi agama ke dalam materi pelajaran yang diberikan. Ada beberapa nilai yang dikembangkan di madrasah sebagai sekolah umum dengan kekhasan Agama Islam yakni nilai akademik dan non-akademik. Dalam wilayah non-akademik, komponen religi-budaya-kebangsaan muncul dalam jargon-jargon akblâq al-karimah, kejujuran, menghormati orang lain, berkarya, menyebarkan kebaikan, sopan santun, nasionalisme, budaya belajar yang giat, tolong menolong, ketaatan beribadah, tauhid dan aqidah, pemikiran, dan ilmu pengetahuan dan teknologi.

Pengembangan nilai-nilai di atas bertujuan untuk menanamkan kepada siswa nilai moral keagamaan yang tinggi dan mampu mengamalkannya pada lingkungan (sekolah, rumah dan masyarakat), sehingga siswa mendapatkan kedudukan yang mulia di masyarakat melalui kemampuan akademik dan non-akademik serta memiliki akhlaq mulia. Dalam pendidikan modern, siswa juga akan mampu melanjutkan ke pendidikan yang lebih tinggi. Dengan demikian, siswa kelak mampu beradaptasi dengan perubahan zaman dengan tetap menjunjung tinggi ajaran Islam. Singkat kata, pengembangan nilai di madrasah bertujuan untuk menciptakan insan yang berhasil di dunia dan akhirat berbekal keseimbangan nilai keagamaan dan keahlian hidup di dunia modern. 
Muhaimin menyebutkan bahwa, kegiatan (pembelajaran) pendidikan agama Islam diarahkan untuk meningkatkan keyakinan, pemahaman, penghayatan, dan pengamalan ajaran agama Islam dari peserta didik, yang di samping untuk membentuk kesalehan atau kualitas pribadi, juga sekaligus untuk membentuk kualitas kesalehan sosial. Dalam arti, kualitas atau kesalehan pribadi tersebut diharapkan mampu memancar ke luar dalam hubungan keseharian dengan manusia lainnya (bermasyarakat), baik seagama ataupun yang berbeda agama, serta dalam berbangsa dan bernegara, sehingga dapat terwujud persatuan dan kesatuan nasional dan juga persatuan dan kesatuan antar-manusia. ${ }^{15}$

Dengan demikian, para pengelola dan pelaksana pendidikan di lembaga pendidikan Islam yang terdiri dari guru dan tenaga administrasi perlu ditingkatkan. Tenaga guru dari segi jumlah dan profesional masih kurang. Guru-guru bidang studi umum (MIPA) masih belum mencukupi. Hal ini sangat berdampak pada outputnya.

Di dalam bidang keilmuan dirumuskan upaya pengintegrasian yang menyatu antara ilmu-ilmu agama dan umum. Penyatuan itu tidak hanya mencakup dengan memasukkan mata pelajaran agama ke sekolah-sekolah umum dan mata pelajaran umum dan mata pelajaran umum ke pesantren dan madrasah. Akan tetapi tidak kalah pentingnya adalah rancangan dari kedua jenis ilmu itu agar ada saling keterkaitan. Upaya-upaya itu dapat dikaitkan dengan dua acara. Pertama, merancang keterkaitan ilmu-ilmu agama dan umum. Materi pelajaran agama tidak hanya berdiri sendiri, dari materi-materi ilmu agama dapat dikaitkan dengan ilmu-ilmu sosial, humaniora dan ilmu-ilmu kealaman. Kedua, merancang nilai-nilai Islami pada setiap mata pelajaran. Adanya keterkaitan ilmu-ilmu tersebut dengan nilai-nilai islam di dalam mengintegrasikan berbagai disiplin ilmu dengan ajaran islam melalui mekanisme penyerapan nilai-nilai Islam kedalam setiap mata pelajaran dan usaha-usaha konsepsisasi keilmuan Islam dengan genre-genre keilmuan sekuler.

Dalam rangka untuk merealisasikan semua aspek pendidikan Islam, maka perlu dirancang keterpaduan antara pendidikan di Sekolah, di Rumah dan di masyarakat dalam satu kesatuan yang terintegrasi. Dalam konteks madrasah, tenaga pendidik non-agama juga dapat berfungsi sebagai pendidik agama, kendatipun secara

15 Muhaimin, et.al, Paradigma Pendidikan Islam (Bandung:Remaja Rosdakarya, 2001), 78. 
formal dia bukan mengajarkan mata pelajaran agama. Lewat mata pelajaran yang diajarkannya, dia bisa mengimplisitkan nilai-nilai Islami. Lebih dari itu yang amat penting adalah tercerminnya nilai-nilai islami dalam seluruh tingkah laku pendidik karena pendidik dituntut memiliki jiwa keislaman yang tinggi.

\section{Dimensi Keagamaan pada Kurikulum Madrasah}

Perhatian umat manusia terhadap pendidikan tidak akan pernah berhenti. Pendidikan setidaknya selalu dijadikan tumpuan umat manusia dalam dua hal. Pertama, sebagai sarana untuk memecahkan persoalan-persoalan kehidupan manusia yang tengah dihadapinya, atau diprediksikan dihadapi di masa mendatang. Kedua, sebagai sarana untuk membangun peradaban manusia, melampaui masalah-masalah yang dihadapinya. Jelasnya pendidikan diperlukan oleh umat manusia untuk keluar dari kesulitan kehidupan hari ini membangun peradaban, atau kehormatan dan kejayaan kehidupan manusia masa yang akan datang. Para ulama Muslim klasik, secara lebih elegan merumuskan fungsi pendidikan semacam itu dalam istilah li sa'âdat al-dârayn. Kehidupan yang akan datang dalam konsep mereka menembus batas kehidupan di dunia dan melampauinya, hingga ke batas yang lebih jauh lagi, yaitu kehidupan akhirat.

Pendidikan diandalkan untuk mengatasi problem "kekinian" dapat dilihat dari kecemasan banyak pihak terhadap kehidupan pada milenium ketiga, atau era global, yang menuntut kemampuan bersaing yang amat tinggi di satu pihak, dan ketangguhan menghadapi perubahan yang amat cepat di pihak lain. Pada situasi seperti itu, banyak masyarakat manusia menaruh harapan terhadap pendidikan. Selama ini, masyarakat Muslim meyakini bahwa "pendidikan (agama) Islam" dapat memenuhi kedua fungsi di atas. Bahkan lebih dari itu, diyakini pula bahwa dalam menunaikan fungsi-fungsi tersebut pendidikan Islam lebih unggul dari pendidikan yang lain. Dasar keyakinan itu ialah karena pendidikan Islam bersumber dari dan sekaligus dituntun oleh wahyu al-Qur'ân. Keyakinan demikian memiliki sisi positif, setidaknya dapat melahirkan kegigihan untuk mempertahankan eksistensi pendidikan Islam, seperti selama ini dapat kita saksikan. Namun demikian, keyakinan seperti itu dapat menghilangkan daya kritis terhadapnya, sehingga pendidikan Islam terasa mandul, seperti yang kita rasakan selama ini.

Terdapat dua realitas yang perlu direnungkan untuk mengritisi pendidikan Islam. Pertama, bahwa masih banyak ketidakharmonisan, 
kemiskinan, dan ketidakberdayaan dalam kehidupan umat Islam. Kedua, tuntutan global yang amat kompleks yang semangat pemecahannya belum tampak dalam praktik pendidikan Islam. Dua realitas tersebut dapat menggugah kita untuk mempertanyakan eksistensi pendidikan (agama) Islam, setidaknya dari sisi materi ajarnya, yaitu antara ilmu dan kompetensi.

Sistem Pendidikan Islam sampai saat ini dirasa masih bersifat ambivalen. Setidaknya hal ini dirasakan oleh A.M Saefuddin yang dikutip oleh Jamali Sahrodi. ${ }^{16}$ Sifat ambivalen yang dimaksud adalah model penyelenggaraan pendidikan agama di Indonesia mengalami ketimpangan dimana di satu pihak pendidikan yang diterapkan di sekolah-sekolah umum hanya sekadar pelengkap, sedangkan penyelenggaraan pendidikan yang dilaksanakan pada sistem pendidikan Islam kurang mengembangkan penguasaan disiplin ilmu (Sains, Tekonologi, dan Keterampilan). Ada anggapan yang berkembang selama ini bahwa penguasaan disiplin ilmu dan keterampilan hanya garapan sistem pendidikan umum. Sistem madrasah yang membagi porsi materi pendidikan Islam dan materi pendidikan umum dalam persentase tertentu telah terbukti mengakibatkan bukan saja pendidikan Islam tidak lagi berorientasi sepenuhnya pada tujuan Islam yang bertujuan membentuk manusia bertakwa, tetapi juga tidak mencapai tujuan pendidikan umum.

Sistem pendidikan Islam yang menampakkan wajah ambivalensi, disintegrasi, eksklusif dan kurang berorientasi pada tujuan pendidikan Islam sendiri perlu pembenahan dan penataan kembali sesuai dengan apa yang digariskan oleh ajaran Islam (berdasarkan al-Qur'ân dan Hadîth). Kondisi semacam ini tentu saja harus dibaca sebagai tantangan yang harus segera diantisipasi secara lebih matang dan terencana serta dituntut untuk memunculkan inovasi-inovasi baru yang mendalam dari masyarakat akademik maupun yang lainnya agar pendidikan Islam tetap diterima oleh masyarakat yang juga terus menerus berubah, tanpa harus kehilangan jati diri sebagai lembaga pendidikan Islam.

Yang terpenting dilakukan oleh madrasah saat ini adalah keberanian untuk menciptakan sesuatu yang up date dan melakukan

16 Jamali Syahrodi, dkk., Membedah Nalar Pendidikan Islam: Pengantar Kearah Ilmu Pendidikan Islam (Yogyakarta: Pustaka Rihlah, 2001), 151-153. 
antisipasi terhadap kebutuhan-kebutuhan tersebut. ${ }^{17}$ Berkaitan dengan hal tersebut terutama upaya para pendidik (guru) dan tenaga kependidikan lainnya dalam mewujudkan makna substantif madrasah sebagai pendidikan umum dengan kekhasan agama Islam ke dalam praktik pengembangan kurikulum di Madrasah Aliyah dapat diungkap melalui sembilan indikator. Pertama, pelaksanaan pengembangan kurikulum yang diimplementasikan dalam bentuk persiapan perangkat pembelajaran, kegiatan pembelajaran, evaluasi, dan memadukan kurikulum Diknas dengan kurikulum Kemenag dalam Lokakarya. Kurikulum memiliki posisi sentral dalam setiap upaya pendidikan. ${ }^{18}$ Posisi sentral ini menunjukkan bahwa di setiap unit pendidikan kegiatan kependidikan yang utama adalah proses interaksi akademik antara peserta didik, pendidik, sumber dan lingkungan, dan menunjukkan pula bahwa setiap interaksi akademik adalah jiwa dari pendidikan. Dapat dikatakan bahwa kegiatan pendidikan atau pembelajaran pun tidak dapat dilakukan tanpa interaksi dan kurikulum adalah desain dari interaksi tersebut. Dalam mengkaji kurikulum Madrasah terkait dengan upaya pendidik dalam mewujudkan makna substantif madrasah sebagai pendidikan umum dengan kekhasan agama Islam, merefleksikan Guba dalam Daniel Linden ${ }^{19}$ Policy is the effect of the policy, madrasah sebagai pelaksana pendidikan akan mengeluarkan beberapa kebijakan dalam mewujudkan visi yang merupakan dampak atau dipengaruhi oleh adanya kebijakan pemerintah. Begitu juga dengan materi yang disampaikan di madrasah, sebagai satuan pendidikan di bawah Kementerian Agama tentu harus mengikuti ketentuan pemerintah yakni yang ditetapkan dalam standar Isi (Permendiknas nomor 22 dan 23 tahun 2006 tentang standar isi dan standar kompetensi lulusan). Meski demikian masing-masing madrasah diberikan kebebasan untuk mengelola dan mengimplementasikan kurikulum sesuai dengan visi, misi, tujuan, situasi dan kondisi madrasah serta tuntutan stakeholders madrasah.

Kedua, model integrasi materi (umum dan Pendidikan Agama Islam) dalam proses pembelajaran diterapkan dalam bentuk mengaitkan materi pelajaran dengan nilai-nilai agama, pemilihan materi dikaitkan dengan PAI, dan metode pembelajaran melalui

17 A. Malik Fadjar, Madrasab dan Tantangan Modernitas (Bandung: Mizan, 1998), 5657.

18 M.F. Klein, Curriculum Reform in the Elementary School: Creating Your Own Agenda (New York dan London: Teachers College, Columbia University, 1989), 15.

${ }^{19}$ Daniel Linden Duke, School Policy (New York: Mc. GrawHill, Inc., 1997), 2. 
pendekatan yang Islami. Secara konsepsional mulai dari kurikulum 1975 hingga lahirnya kurikulum 1994 dan bahkan dalam kurikulum KBK 2004 dan KTSP 2006, dikotomisasi ilmu pengetahuan umum dan agama madrasah telah dihilangkan melalui pemberian ilmu pengetahuan umum dan ilmu pengatahuan keagamaan kepada siswa secara bersamaan. Akan tetapi jika ditelusuri lebih jauh, penyatuan tersebut masih belum memenuhi harapan. Hal itu ditandai dengan adanya konsep dan desain kurikulum yang terpisah antara ilmu pengetahuan umum dan agama (separated subject matter curriculum). Dalam hal itu, antara mata pelajaran umum dengan mata pelajaran agama tidak didesain secara terintegrasi. Lebih khusus lagi dalam hal itu, konsep dan desain kurikulum mata pelajaran umum (seperti Biologi, Fisika, dan Kimia) tidak atau masih belum mengintegrasikan imtaq di dalamnya. Jika mengacu pada tiga model pengintegrasian antara ilmu dengan agama, maka berdasarkan penelitian yang dilakukan model diadik dialogis adalah model yang banyak digunakan. Hal ini dapat dilihat dari adanya materi agama dan umum yang dapat diintegrasikan satu sama lain, akan tetapi ada materi yang belum dapat diintegrasikan karena belum adanya pengetahuan tentang hal tersebut, sehingga keduanya memiliki kebenaran masing-masing.

Ketiga, model integrasi materi (umum dan Pendidikan Agama Islam) dalam bentuk pemilihan media pembelajaran dan bahan ajar yang diimplementasikan dalam bentuk media pembelajaran Islami baik isi maupun ilustrasinya, terutama gambar-gambar dan tes bacaan yang memuat nilai-nilai pendidikan Islam. Salah satu faktor pendukung Pendidikan Islam yang memberikan sumbangan cukup besar adalah tersedianya bahan pembelajaran yang dapat membantu memudahkan belajar peserta didik. Buku ajar sebagai salah satu bentuk sumber belajar, di samping sebagai pengembangan pembelajaran juga merupakan komponen sistem pembelajaran yang perlu diperhatikan, terutama dari segi rancangan yang sesuai dengan prinsip-prinsip pembelajaran. Untuk mencapai tujuan pembelajaran diperlukan penyediaan dan pemanfaatan sumber belajar, pengembangan proses belajar mengajar yang memungkinkan terjadinya interaksi dengan berbagai sumber belajar yang memudahkan untuk mencapai tujuan. Karena itu proses interaksi dapat dikembangkan secara sistemik dan 
dikelola dengan baik. ${ }^{20}$ Oleh karena itu, agar upaya para pendidik (guru) dan tenaga kependidikan lainnya dalam mewujudkan makna substantif madrasah sebagai pendidikan umum dengan kekhasan agama Islam ke dalam praktik pengembangan kurikulum dapat berhasil dengan baik, maka perlu disusun media pembelajaran Islami baik isi maupun ilustrasinya.

Keempat, hal yang dilakukan jika terjadi benturan konsep antara mapel umum dengan agama Islam yang diimplementasikan dalam bentuk koordinasi dengan guru yang lebih kompeten, penyampaian pandangan dari sisi umum dan dari sisi agama Islam, diskusi, dan pengambilan kesimpulan bersama-sama antara guru dan siswa. Muhaimin $^{21}$ mengemukakan bahwa pengintegrasian IMTAQ dengan mengintegrasikan konsep atau ajaran agama ke dalam materi (teori dan konsep) yang sedang dipelajari oleh peserta didik atau diajarkan oleh pendidik/guru. Hal ini bisa dilakukan dengan beberapa cara, yaitu: pertama, pengintegrasian filosofis, yakni bila tujuan fungsional mata pelajaran umum sama dengan tujuan fungsional mata pelajaran agama. Misalnya Islam mengajarkan perlunya hidup sehat, sementara itu ilmu kesehatan juga mengajarkan hal yang sama. Kedua, pengintegrasian dilakukan karena konsep agama berlawanan dengan konsep pengetahuan umum, misalnya guru ekonomi mengajarkan bunga bank boleh sedangkan guru PAI mengajarkan bunga bank haram. Hal-hal yang berlawanan tersebut harus diselesaikan dan peserta didik jangan sampai diajari konsep yang berlawanan. Misalnya untuk kasus bunga bank dapat dipertemukan dengan menjelaskan kepada peserta didik bahwa bank memiliki banyak karyawan yang semuanya harus diberi gaji, dari mana gaji mereka? Maka salah satunya diambil dari bunga bank tersebut. Karena itu bunga bank masih dapat ditolelir asalkan bunganya tidak terlalu tinggi, sehingga sangat membebani pada nasabah. Ketiga, pengintegrasian dilakukan jika konsep agama saling mendukung dengan konsep pengetahuan umum. Misalnya: guru Ilmu Kesehatan mengajarkan bahwa kebanyakan penyakit berasal dari makanan, sehingga diet perlu dilakukan untuk kesehatan. Guru Ilmu Kesehatan dapat meneruskan bahwa puasa

20 Y. Miarso, A. Haryono, Natakusumah dkk, Teknologi Komunikasi Pendidikan: Pengertian dan Penerapannya di Indonesia (Jakarta: Pustekkom Dikbud dan CV Rajawali ECD Project USAID, 1987).

${ }^{21}$ Muhaimin, Pengembangan, 43-44. 
adalah diet yang sangat baik. Cukup begitu saja, tidak perlu diberikan dalil al-Qur'ân dan Hadîth atau uraian yang bertele-tele.

Kelima, perencanaan pembelajaran (Silabus dan RPP) dalam rangka pengembangan kurikulum Madrasah sebagai pendidikan umum dengan kekhasan agama Islam yang diimplementasikan dalam bentuk: membuat RPP/Silabus di awal tahun pembelajaran. Dalam pembuatan silabus, RPP dimasukkan character building, mencari literatur yang sekiranya ada kaitannya dengan dengan materi pelajaran umum, seperti al-Qur'ân dan Hạîtth dan dalam RPP dan silabus dicantumkan materi yang kemudian dihubungkan dengan ayat-ayat yang ada dalam al-Qur'ân atau Hadîth-Hạâth kalau memang ada (kolom khusus IMTAQ). Dalam rangka pengembangan kurikulum di madrasah upaya yang dilakukan pemerintah di antaranya, Departemen Pendidikan dan Kebudayaan RI telah menerbitkan "Naskah Keterkaitan 10 Mata Pelajaran Umum di SMU dengan Imtaq" (Depdikbud, 1996), yang juga diberlakukan di MA sebagai Sekolah Umum yang berciri khas Islam. Dalam naskah tersebut setiap materi pelajaran IPTEK diberi materi landasan imtaq berupa ayat-ayat al-Qur'ân dan Hadîth yang dapat digunakan sebagai pedoman dan acuan bagi guru mata pelajaran umum dalam rangka integrasi IPTEK dan IMTAQ. Meski kemudian upaya tersebut kurang berhasil karena beberapa hal antara lain: kurikulum masih didesain secara terpisah-pisah; belum adanya model dan pedoman kurikulum dan pembelajaran terpadu yang dapat menunjang pembentukan integrasi pengetahuan tersebut, di samping kemampuan guru dan sarana yang belum memadai. Pelaksanaan program integrasi ilmu agama dan umum, dapat mengacu pada konsep kurikulum yang oleh para ahli pendidikan disebut sebagai integrated curriculum yang dapat dilakukan dalam bentuk antara lain: 1) keterpaduan dalam satu bentuk disiplin ilmu, 2). Keterpaduan lintas bidang studi, dan 3). Keterpaduan dalam dan lintas siswa. ${ }^{22}$

Keenam, guru mapel umum melakukan diskusi dengan guru PAI dalam penyusunan perencanaan pembelajaran (Silabus dan RPP) terhadap materi yang bisa menimbulkan benturan konsep yang diimplementasikan dalam bentuk: diskusi berkala (di awal tahun pelajaran). Forum yang digunakan oleh guru antara lain adalah Kelompok Kerja Guru (KKG) maupun Musyawarah Guru Mata Pelajaran (MGMP). KKG atau MGMP sendiri adalah wadah

\footnotetext{
22 Syaifudin Sabda, "Pembaharuan Kurikulum Pendidikan Islam: Model Kurikulum Pendidikan Terpadu”, Jurnal Khazanah, Vol. 1, No. 2 (2002), 188.
} 
berkumpulnya para guru dalam satu gugus tersebut untuk memecahkan masalah, menguji coba dan mengembangkan ide-ide baru untuk peningkatan mutu KBM, serta meningkatkan profesionalisme guru. Sedangkan rapat madrasah adalah kelompok guru dari satu madrasah, yang secara berkala berkumpul di sekolahnya dipimpin oleh Kepala Madrasah untuk memecahkan masalah mereka sendiri. Beberapa madrasah menyebut kegiatan ini dengan nama KKG/MGMP Tingkat Madrasah. Untuk di madrasah penyusunan perangkat pembelajaran biasanya dilakukan pada tiap awal tahun pelajaran melalui kegiatan workshop dan lokakarya. Materi kurikulum harus mampu menyentuh semua fitrah kemanusian peserta didik, baik fitrah rohani, akal dan perasaan, sehingga memberi corak dan mewarnai segala aktivitas kehidupannya dimuka bumi baik sebagai 'abd maupun khaliffah. Ilmu-ilmu agama dan ilmu umum pada dasarnya dapat diintegrasikan menjadi satu isi materi kurikulum. Integrasi tersebut dalam kurikulum dapat dilakukan secara kualitatif dan kuatitatif. Integrasi secara kualitatif, artinya porsi pendidikan umum dan pendidikan agama diberikan secara seimbang, sedangkan secara kualitatif, menjadikan pendidikan umum diperkaya dengan nilai-nilai agama, dan pendidikan agama diperkaya dengan muatan yang ada dalam pendidikan umum. Nilai agama memberikan makna dan semangat terhadap program pendidikan umum. Dengan integrasi dalam kegiatan pembelajaran diharapkan peserta didik dapat memahami esensi ilmu secara utuh dan holistik, mengetahui tujuan dan mampu mengamalkannya sesuai dengan fungsi manusia sebagai 'abd dan khalifah.

Ketujuh, pelaksanaan pembelajaran (di kelas dan di luar kelas) dalam rangka pengembangan kurikulum madrasah sebagai pendidikan umum dengan kekhasan agama Islam yang diimplementasikan dalam bentuk pelaksanaan ajaran Islam dalam KBM baik di dalam maupun diluar kelas (keteladanan), variasi pembelajaran dan pembudayaan Islam dalam pembelajaran di dalam dan luar kelas. Secara eksplisit dapat diketahui pemilihan yang dilakukan terhadap materi pembelajaran dengan memberikan nuansa islami dan pemilihan media pembelajaran serta bahan ajar yang dipilih adalah untuk memberikan nuansa integratif antara ilmu umum dan agama. Nuansa integratif yang muncul pada setiap pembelajaran di dalam kelas akan memberikan kaitan kuat antara ilmu umum dan agama, sehingga ilmu pengetahuan tidak akan tercerabut dari akar kebenaran absolut dari 
agama. Sebagai sebuah kesatuan utuh ilmu dalam Islam tidaklah mengenal dikotomi ilmu, karena ilmu adalah alat untuk memperoleh dan mengetahui kebenaran penciptaan Allah. Pengintegrasian IMTAQ dalam proses pembelajaran dapat dilakukan dengan bertolak dari konsep, bahwa pada setiap proses pembelajaran diupayakan untuk tidak sampai berlawanan dengan ajaran agama Islam.

Kedelapan, produk (bahan ajar, media pembelajaran, dan lain-lain) yang dihasilkan sebagai perwujudan implementasi pengembangan kurikulum madrasah yang diimplementasikan dalam bentuk: Modul, RPP, Media ICT (VCD), Silabus, power point yang relevan dengan pembelajaran dan $A$ flow chart of speaking. Integrasi ilmu umum dan agama dalam pembelajaran dengan melakukan pemilihan media pembelajaran dimaksudkan untuk menjelaskan dan membiasakan kepada peserta didik bahwa nilai-nilai agama akan selalu muncul beriringan dengan kondisi sosial kemasyarakatan, sehingga pendidikan yang dilakukan tidaklah terasing dari persoalan yang terjadi di masyarakat. Dengan demikian, di madrasah perlu dilakukan upaya spiritualisasi pendidikan atau berupaya menginternalisir nilai-nilai atau spirit agama melalui proses pendidikan ke dalam seluruh aspek pendidikan di madrasah. Hal ini dimaksudkan untuk memadukan nilai-nilai sains dan teknologi serta seni dengan keyakinan dan kesalehan dalam diri peserta didik. Ketika belajar Biologi misalnya, maka pada waktu yang sama diharapkan pelajaran itu dapat meningkatkan keimanan dan ketakwaannya kepada Allah, karena di dalam ajaran agama diterangkan bahwa Tuhanlah yang telah menciptakan keaneka-ragaman (biodiversity) di muka bumi ini dan semuanya tunduk pada hukum-hukum-Nya. ${ }^{23}$ Strategi penguatan kekhasan agama Islam juga bisa dilakukan melalui upaya pengembangan budaya agama dalam komunitas madrasah, yang berarti bagaimana mengembangkan agama Islam di madrasah sebagai pijakan nilai, semangat, sikap, dan perilaku bagi para aktor madrasah, seperti kepala madrasah, guru dan tenaga kependidikan lainnya, orang tua murid, dan peserta didik itu sendiri. ${ }^{24}$

Kesembilan, guru mapel umum menganalisis bahan ajar yang ada dengan kekhasan agama Islam meski hanya sebagian guru melakukan analisis terhadap bahan ajar yang ada dengan kekhasan agama Islam. Bahan ajar yang beredar di pasaran sangat banyak, maka salah atu

23 Ibid., 133.

${ }^{24}$ Ibid. 
upaya yang dilakukan dalam mewujudkan makna substantif madrasah sebagai pendidikan umum dengan kekhasan Agama Islam adalah menganalisis bahan ajar yang ada untuk dipilih yang sesuai dengan ajaran Islam. Hal ini dilakukan bagi guru yang belum dapat menyusun bahan ajar secara mandiri, sehingga hanya memanfaatkan bahan ajar yang ada.

Zainal Abidin Bagir, dkk mengemukakan bahwa ilmu mampu membantu agama merevitalisasi diri dengan beberapa cara. ${ }^{25}$ Pertama, kesadaran kritis dan sikap realistis yang dibentuk oleh ilmu sangat berguna untuk mengelupaskan sisi-sisi ilusoris agama, bukan untuk menghancurkan agama, melainkan untuk menemukan hal-hal yang lebih esensial dari agama. Dalam praksisnya, banyak hal dalam kehidupan beragama yang mungkin saja bersifat ilusoris, yang membuat agama-agama bersifat over-sensitive sehingga mudah menimbulkan konflik yang akhirnya justru menggerogoti martabat agama sendiri tanpa disadari. Kedua, kemampuan logis dan kehatihatian mengambil kesimpulan yang dipupuk dalam dunia ilmiah menjadikan kita mampu menilai secara kritis segala bentuk tafsir baru yang kini makin hiruk-pikuk dan membingungkan. Ketiga, lewat temuan-temuan barunya. Ilmu dapat merangsang agama untuk senantiasa tanggap memikirkan ulang keyakinan-keyakinannya secara baru dengan begitu menghindarkan agama itu sendiri dari bahaya stagnasi dan pengaratan. Keempat, temuan-temuan ilmu pengetahuan dan teknologi pun dapat memberi peluang-peluang baru bagi agama untuk makin mewujudkan idealisme-idealismenya secara konkret, terutama yang menyangkut kemanusiaan umum.

Hubungan antara ilmu agama yang bersifat timbal balik adalah kerangka utama dari pengembangan pendidikan yang berbasis nilainilai perennial dan nilai-nilai keagamaan. Hubungan yang bersifat mutual akan membawa tujuan akhir dari pendidikan yang sesuai dengan fitrah penciptaan manusia. Dalam persoalan penciptaan manusia dan tujuan penciptaannya, Islam melihat manusia sebagai ultimate creation yang mampu mencerna nilai-nilai ketuhanan dalam internal penciptaan-Nya dan mampu mengambil kesimpulan dari tanda-tanda yang diberikan lewat segala penciptaan Allah.

Komponen pendidikan yang terdiri dari tujuan, materi, metode, evaluasi, situasi, sarana-prasarana dan lain-lain adalah syarat utama

25 Zainal Abidin Bagir, dkk., Integrasi Ilmu dan Agama: Interpretasi dan Aksi (Bandung: Mizan Pustaka, 2005), 45-46. 
dalam menjalankan program pendidikan, sehingga dapat dicapai tujuan dari pendidikan tersebut. Kondisi yang terjadi pada pendidikan di Indonesia yang menganut sistem dikotomi menyebabkan kebijakan terhadap lembaga penyelenggara pendidikan juga beragam. Political will pemerintah terkait aspek budgeting terhadap lembaga pendidikan yang bernaung di bawah kemeterian agama dan kementerian pendidikan nasional juga berbeda. Berdasarkan data yang dikeluarkan Center for Informatics Data and Islamic Studies (CIDIES) Kementerian Agama dan data base EMIS (Education Management System) Dirjen Pendidikan Islam Kementerian Agama, jumlah madrasah (Madrasah Ibtidaiyah/MI (SD), Madrasah Tsanawiyah/MTs (SMP) dan Madrasah Aliyah/MA (SMA) sebanyak 36.105 madrasah (tidak termasuk madrasah diniyah dan pesantren). Dari jumlah itu 90,08 \% berstatus swasta dan hanya $9,92 \%$ yang berstatus negeri.

Peningkatan mutu pendidikan secara merata adalah persoalan mutlak bagi eksistensi sebuah bangsa dengan tanpa membedakan identitas kultural masyarakatnya. Menempatkan madrasah sebagai lembaga pendidikan kelas dua atau menomorduakan peningkatan mutu bagi madrasah setelah lembaga persekolahan tidak dapat dibenarkan dalam perspektif apapun. Untuk mempercepat peningkatan mutu madrasah secara efektif, diperlukan pemahaman terhadap hakekat dan problematika madrasah. Madrasah sebenarnya merupakan model lembaga pendidikan yang ideal karena menawarkan keseimbangan hidup: iman-takwa (imtaq) dan ilmu pengetahuanteknologi (IPTEK). Di samping itu, sebagai lembaga pendidikan berbasis agama dan memiliki akar budaya yang kokoh di masyarakat, madrasah memiliki basis sosial dan daya tahan yang luar biasa. Atas dasar itu apabila madrasah mendapatkan sentuhan menejemen dan kepemimpinan yang baik niscaya akan dengan mudah menjadi madrasah yang diminati masyarakat. Seandainya mutu madrasah itu sejajar saja dengan sekolah, niscaya akan dipilih masyarakat, apalagi kalau lebih baik.

Dalam pengembangan kurikulum pendidikan dikenal beberapa paradigma pengembangan. Setidaknya ada tiga paradigma yang sering dipakai dalam proses pengembangan kurikulum di lembaga pendidikan di Indonesia. Pertama, paradigma formisme atau dikotomis. Dalam paradigma ini segala sesuatu dilihat dari dua sisi yang berbeda, seperti ada dan tidak ada, pendidikan agama dan pendidikan umum dan seterusnya yang pada akhirnya berkembang 
pada aspek dunia dan akhirat, sehingga menimbulkan dualisme dalam sistem pendidikan. Paradigma ini berimplikasi terhadap pengembangan PAI yang lebih berorientasi pada keakhiratan. Sedangkan masalah dunia dianggap tidak penting dan terpisah dari agama. Pendekatan yang digunakan lebih bersifat keagamaan yang normatif, doktriner dan absolut.

Kedua, paradigma mekanisme. Paradigma mekanisme memandang kehidupan terdiri atas bebagai aspek, dan pendidikan dipandang sebagai penanaman dan pengembangan seperangkat nilai kehidupan, yang masing-masing bergerak dan berjalan menurut fungsinya. Nilainilai kehidupan itu terdiri atas nilai agama, nilai individu, nilai sosial, politik, ekonomi, dan lain-lain. Hubungan antara nilai agama dengan nilai nilai lainnya kadang-kadang bersifat horizontal-lateral (independen) atau bersifat lateral-sekuensial, tetapi tidak sampai pada vertikal-linier.

Ketiga, paradigma organisme atau organisasi. Paradigma organisme mempunyai pandangan bahwa aktivitas kependidikan merupakan suatu sistem yang terdiri atas komponen-komponen yang hidup bersama dan bekerjasama secara terpadu menuju tujuan tertentu, yaitu terwujudnya hidup yang religius. Ajaran dan nilai-nilai beragama dijadikan sebagai sumber konsultasi yang bijak, sementara aspek-aspek kehidupan lainnya ditempatkan sebagai nilai-nilai insani yang mempunyai hubungan vertikal-linier dengan nilai agama. Paradigma tersebut tampaknya mulai dirintis dan dikembangkan dalam sistem pendidikan di madrasah, yang dideklarasikan sebagai sekolah umum yang berciri khas agama Islam.

Melihat realitas yang terjadi di lapangan model pengembangan kurikulum tersebut jelas seperti dalam model pengembangan kurikulum dengan mengacu pada paradigma organisme. Model paradigma ini mulai marak dikembangkan pada madrasah yang memiliki sistem pendidikan Islam. Madrasah yang dideklarasikan sebagai sekolah umum berciri khas agama Islam. Kebijakan yang dibuat oleh madrasah haruslah mengakomodir tiga kepentingan utama yaitu; 1) sebagai wahana untuk membina ruh atau praktik hidup keislaman; 2) memperjelas dan memperkokoh keberadaan madrasah sederajat dengan sistem sekolah umum sebagai wahana pembinaan warga negara yang cerdas, berpengetahuan, berkepribadian, serta produktif; dan 3) mampu merespons tuntutan-tuntan masa depan, 
dalam arti sanggup melahirkan manusia yang memiliki kesiapan memasuki era globalisasi, industrialisasi maupun era informasi.

\section{Strategi Penguatan Karakter Keagamaan dalam Pengembangan Kurikulum}

Untuk mengimbangi perkembangan sekularisme di dunia pendidikan, masyarakat Muslim-terutama para reformis-berusaha melakukan reformasi melalui upaya pengembangan pendidikan dan pemberdayaan madrasah. ${ }^{26}$ Platform pendidikan yang diadopsi adalah pendidikan sekuler, tetapi isi dan nuansanya adalah keislaman. Salah satu upaya pengembangan pendidikan dan pemberdayaan Madrasah dapat dilakukan melalui pengembangan kurikulum yang dilakukan secara terus menerus dan berkelanjutan baik dalam aspek perencanaan, implementasi maupun evaluasinya. ${ }^{27}$ Hanya saja dalam tradisi masyarakat kita, pengembangan kurikulum lebih banyak disibukkan dan/atau berhenti pada aspek curriculum plan (kurikulum sebagai dokumen), yang meliputi: (1) perumusan standar kompetensi lulusan; (2) penentuan serangkaian mata pelajaran; (3) penyusunan silabus; dan (4) penyusunan Rencana Pelaksanaan Pembelajaran (RPP). Sedangkan pada aspek actual curriculum atau kegiatan nyata biasanya terlupakan, seperti masalah proses pembelajaran, proses evaluasi (assessment) termasuk di dalamnya uji kompetensi, dan penciptaan suasana pembelajaran. Padahal, apa artinya kurikulum sebagai dokumen jika tidak ditindaklanjuti dengan acual curriculum. Karena itu, dalam kegiatan pengembangan kurikulum ini perlu memperhatikan keduaduanya.

Pengembangan pendidikan madrasah tidak dapat ditangani secara parsial, tetapi memerlukan pemikiran pengembangan yang utuh sebagai konsekuensi dari identitasnya sebagai sekolah umum yang berciri khas agama Islam terutama ketika dihadapkan pada kebijakan pembangunan nasional bidang pendidikan yang menekankan pada peningkatan kualitas Sumber Daya Manusia. ${ }^{28}$

Arah Kebijakan pengembangan kualitas madrasah kedepan hendaknya diupayakan untuk memenuhi tiga tuntutan minimal yaitu: (1) Bagaimana menjadikan madrasah sebagai wahana untuk membina ruh atau praktik hidup keagamaan; (2) Bagaimana memperkokoh

\footnotetext{
${ }^{26}$ Muhaimin, Pengembangan, 183.

${ }^{27}$ Ibid., 12-13.

28 Muhaimin, Arah Baru Pengembangan Pendidikan Islam: Pemberdayaan, Pengembangan Kurikulum, hingga Redefinisi Islamisasi Ilmu Pengetahuan (Bandung: Nuansa, 2002), 197.
} 
keberadaan madrasah sehingga sederajat dengan sistem sekolah; dan (3) bagaimana madrasah mampu merespons tuntutan masa depan guna mengantisipasi perkembangan IPTEK dan era globalisasi. ${ }^{29}$

Madrasah sebagai sebuah lembaga pendidikan yang di dalamnya diajarkan materi keagamaan hendaknya bukan hanya berfungsi sebagai pelestarian nilai-nilai keagamaan saja, melainkan juga berfungsi untuk mendorong pengembangan kecerdasan dan kreativitas peserta didik, serta pengembangan tenaga yang produktif, inovatif, yang memiliki daya pesaing, sabar, rendah hati, menjaga harga diri (self-esteem), berempati, mampu mengendalikan diri (self controh), berakhlaq mulia, bersikap amanah dalam menjalankan tugas yang dibebankan kepadanya. Sedangkan nilai-nilai hidup yang berupa nilai-nilai sosial atau persaudaraan (lokal, daerah, nasional, regional dan global), rasional-etik, efisien manusiawi, kekuasaan untuk mengabdi, estetik kreatif, sehat sportif, dan informatif bertanggung jawab. ${ }^{30}$

Upaya untuk membangkitkan masyarakat belajar yang profesional di Madrasah memerlukan kemampuan, kesiapan, niat atau tekad yang kuat, serta sikap kebersamaan dari semua warga madrasah, yang dipelopori oleh kepala madrasah, dan didukung oleh pengurus yayasan, BP3 atau Majelis Madrasah, serta diikuti oleh para guru dan staf lainnya untuk berpartisipasi dalam melakukan pengembangan dan pembaharuan di Madrasah guna menatap masa depan yang lebih baik, serta didukung oleh aturan-aturan dan kebijakan yang fleksibel baik dari Kanwil maupun pemerintah pusat. ${ }^{31}$ Berbagai program pengembangan tersebut hendaknya dilakukan pada seluruh elemen dalam madrasah mulai dari reorientasi visi dan misi sebagai landasan dalam pelaksanaan pendidikan, materi yang menunjang tercapainya tujuan, adanya sarana dan prasarana serta pendanaan yang cukup.

Dalam praktiknya, proses integrasi ilmu dan agama melalui pembelajaran akan sangat ditentukan oleh kemampuan guru dalam meramu sebuah perencaan pembelajaran, karena ramuan rencana pembelajaran memang merupakan kewajiban pokok seorang guru sebelum dia melakukan interaksi pembelajaran bersama peserta didiknya.

Selain diperlukan sosok guru ideal yang mampu membuat ramuan perencanaan pembelajaran berbasis IMTAK dan IPTEK, dukungan

\footnotetext{
${ }^{29}$ Ibid., 211.

${ }^{30}$ Muhaimin, Pengembangan, 217-218.

${ }^{31}$ Muhaimin, Wacana Pengembangan Pendidikan Islam (Surabaya: PSAPM, 2003), 200.
} 
iklim dan budaya sekolah pun akan sangat menentukan hasil dari proses integrasi. Demikian halnya dengan ketersediaan sarana dan prasarana yang mendukung. Peran kepemimpinan dari seorang kepala sekolah akan sangat menentukan hal tersebut dapat terwujud. Di samping peran serta yang optimal dari seluruh perangkat sekolah.

Selain melalui upaya di atas, apa yang diungkapkan oleh Zainal Abidin Bagir, dkk ${ }^{32}$ dapat menjadi referensi para praktisi pendidikan di lingkungan persekolahan dalam mengintegrasikan IPTEK dan IMTAK. Menurutnya bahwa terdapat empat tataran implemetasi integrasi IPTEK dan IMTAK, yaitu tataran konseptual, institusional, operasional, dan arsitektural.

Dalam tataran konseptual, integrasi IPTEK dan IMTAK dapat diwujudkan melalui perumusan visi, misi, tujuan dan program sekolah (rencana strategis sekolah), adapun secara institusional, integrasi dapat diwujudkan melalui pembentukan institution culture yang mencerminkan paduan antara IPTEK dan IMTAK, sedangkan dalam tataran operasional, rancangan kurikulum dan esktrakulikuler (Kurikulum Tingkat Satuan Pendidikan/KTSP) harus diramu sedemikian rupa, sehingga nilai-nilai fundamental agama dan ilmu terpadu secara koheren. Sementara secara arsitektural, integrasi dapat diwujudkan melalui pembentukan lingkungan fisik yang berbasis IPTEK dan IMTAK.

Strategi penguatan kekhasan Islam dalam rangka mendukung praktik pengembangan kurikulum di Madrasah menurut Muhaimin dibedakan menjadi tiga, yakni: (1) power strategy, yakni strategi pembudayaan agama di madrasah dengan cara menggunakan kekuasaan atau melalui people's power. Dalam hal ini peran kepala madrasah dengan segala kekuasaannya sangat dominan dalam melakukan perubahan; (2) persuasive strategy, yang dijalankan lewat pembentukan opini dan pandangan masyarakat atau warga madrasah; dan (3) normative re-educative. Norma adalah aturan yang berlaku di masyarakat. Norma termasyarakatkan lewat education. Normative digandengkan dengan re-educative (pendidikan ulang) untuk menanamkan dan mengganti paradigma berpikir masyarakat madrasah yang lama dengan yang baru. ${ }^{33}$

\footnotetext{
32 Bagir, Integrasi, 108.

33 Muhaimin, Nuansa Baru Pendidikan Islam: Mengurai Benang Kusut Dunia Pendidikan (Jakarta: Raja Grafindo Persada, 2006), 157-158.
} 
MAN 3 Malang menerapkan tiga strategi penguatan dan pengembangan kurikulum yang bersifat pemeliharaan mutu dan pengembangan. Pertama, bentuk monitoring dan evaluasi yang dilakukan madrasah melalui evaluasi dilakukan untuk bidang akademik dan non-akademik. Pelaksana evaluasi adalah pimpinan madrasah melaksanakan monitoring dan evaluasi 1 dan 2 minggu sekali dan bersifat insidental. Kegitan ini dapat melalui rapat dinas, langsung ke kelas, dan evaluasi perangkat pembelajaran guru. Kedua, kebijakan madrasah sebagai implementasi pengembangan kurikulum Madrasah dilakukan melalui Pengangkatan wakil kepala bidang Keagamaan, Workshop penyusunan perangkat pembelajaran, pelaksanaan kegiatan keislaman bagi siswa, dan kegiatan pembiasaan dan pembuatan Silabus dan RPP dengan tambahan materi agama bagi guru. Ketiga, Strategi penguatan kekhasan agama Islam untuk mendukung praktik pengembangan kurikulum, diwujudkan dalam dua strategi pokok yakni kegiatan rutin dan kegiatan pembiasaan. Contoh kegiatan rutin yang dilakukan misalnya bimbingan membaca al-Qur'ân bagi kelas X, salat Zuhur dan Asar, mengaji dan membaca asmâ' al-ḥusnâ sebelum pelajaran, berdoa sebelum pelajaran. Sedangkan pembiasaan meliputi puasa senin-kamis bagi siswa-guru dan Kegiatan ekstrakulikuler. Kegiatan pembiasaan yang bersifat khusus bagi guru terimplementasi dalam kegiatan penyusunan rencana kegiatan akademik dan nonakademik yang disesuaikan dengan Visi, Misi dan Renstra Madrasah.

Temuan tersebut menunjukkan bahwa madrasah telah melakukan tiga strategi pemeliharaan dan peningkatan mutu. Pertama, penerapan power strategy melalui pengangkatan wakil kepala keagamaan, sehingga seluruh kegiatan keagamaan di madrasah dapat dikontrol dengan baik. Kedua, persuasive strategy melalui bentuk kegiatan (wajib, pembiasaan, ekstrakurikuler, pemberian hukuman kepada siswa dengan hukuman yang dapat meningkatkan IMTAQ). Ketiga, normative re-educative melalui pemanfaatan teknologi untuk meningkatkan pengamalan ajaran Islam serta mempertahankan kekhasan Islam di madrasah. Selain strategi tersebut, perencanaan yang matang serta monitoring dan evaluasi yang dilakukan oleh Kepala Madrasah sangat penting peranannya untuk mengetahui kondisi aktual madrasah.

\section{Penutup}

Pengembangan kurikulum madrasah sebagai sekolah umum dengan kekhasan agama Islam di MAN 3 Malang tidak hanya dipahami secara sempit, tetapi juga dipahami secara lebih luas. Untuk 
mewujudkan nilai-nilai al-akblâq al-karîmah, tidak hanya dilakukan melalui integrasi imtaq ke dalam mata pelajaran umum, tetapi juga dilakukan melalui penciptaan suasana dan tradisi keagamaan yang dikembangkan di madrasah, serta menjadikan masjid sebagai bagian yang tidak terpisahkan dari sebuah proses pembelajaran untuk mewujudkan lulusan sesuai dengan profil yang diharapkan.

Hal itu memperkuat teori yang dikemukakan oleh Muhaimin, bahwa ditinjau dari perspektif historis-filosofis, lahirnya madrasah adalah berawal dari pesantren atau merupakan perkembangan modern dari pesantren, sehingga pengembangan kurikulum madrasah seharusnya memperhatikan karakteristik pondok pesantren, yaitu: adanya kiai, berarti kepala madrasah sebagai kiai dan guru sebagai ustaz/ustazah, memperlakukan peserta didik sebagai siswa sekaligus santri, sehingga siswa/santri memiliki kedekatan dan hubungan emosional dengan kiai/ustaz/ustazah; adanya pengajian kitab, berarti madrasah sebagai wahana pendalaman agama Islam, serta pembinaan ruh dan praktik hidup keagamaan Islam; adanya tempat ibadah/masjid, untuk mendekatkan hati siswa/santri dengan tempat ibadah; serta adanya pondok, untuk menciptakan konteks atau suasana kehidupan yang mencerminkan nilai-nilai islami.

Hal baru dalam temuan penelitian ini adalah dalam medesain kurikulum harus secara terintegrasi bukan separated dan hal ini berimplikasi pada pengadaan guru, yakni guru harus memiliki pemahaman yang baik tentang materi pelajaran yang diampu dan pengetahuan keagamaan.

\section{Daftar Rujukan}

Bagir, Zainal Abidin dkk. Integrasi Ilmu dan Agama: Interpretasi dan Aksi. Bandung: Mizan Pustaka, 2005.

Djalil, Abd. W awancara. Malang, 17-19 Juni 2010.

Duke, Daniel Linden. School Policy. New York: Mc. GrawHill, Inc., 1997.

Fadjar, A. Malik. Madrasah dan Tantangan Modernitas. Bandung: Mizan, 1998.

Furchan, Arief. "Pemberdayaan Madrasah dan Tantangan Globalisasi", makalah disajikan dalam Seminar Sehari di Pondok Pesantren Zainul Hasan Genggong, 25 April 1999.

Ismail, Faisal. Paradigma Kebudayaan Islam: Studi Kritis dan Refleksi Historis. Yogyakarta: Titian Ilahi Press, 1996. 
Klein, M.F. Curriculum Reform in the Elementary School: Creating Your Own Agenda. New York dan London: Teachers College, Columbia University, 1989.

Langgulung, Hasan. Asas-asas Pendidikan Islam. Jakarta: Pustaka AlHusna, 1988.

Masduki. Seri Informasi Pendidikan Islam Indonesia No. 6: Menelusuri Pertumbuban Madrasah di Indonesia. Jakarta: Direktorat Jendral Kelembagaan Agama Islam, Depag RI, 2001.

Miarso, Y., Haryono, A., Natakusumah dkk. Teknologi Komunikasi Pendidikan: Pengertian dan Penerapannya di Indonesia. Jakarta: Pustekkom Dikbud dan CV Rajawali ECD Project USAID, 1987.

Muhaimin, et.al. Paradigma Pendidikan Islam. Bandung:Remaja Rosdakarya, 2001.

Muhaimin. Arah Baru Pengembangan Pendidikan Islam: Pemberdayaan, Pengembangan Kurikulum, bingga Redefinisi Islamisasi Ilmu Pengetahuan. Bandung: Nuansa, 2002.

-----. Nuansa Baru Pendidikan Islam: Mengurai Benang Kusut Dunia Pendidikan. Jakarta: Raja Grafindo Persada, 2006.

-----. Pengembangan Kurikulum Pendidikan Agama Islam di Sekolab: Madrasab dan Perguruan Tinggi. Jakarta: PT RajaGrafindo Persada, Cet. Ke-4, 2010.

-----. Wacana Pengembangan Pendidikan Islam. Surabaya: PSAPM, 2003.

Puslitbang Pendidikan Agama dan Keagamaan, Manajemen Madrasah. Jakarta: Badan Litbang dan Diklat Kementerian Agama RI, 2006.

Puslitbang Pendidikan Agama dan Keagamaan, Respons Masyarakat Terhadap Reposisi Madrasah sebagai Pendidikan Umum Menurut UU Nomor 20 Tahun 2003 tentang Sistem Pendidikan Nasional. Jakarta: Badan Litbang dan Diklat Kementerian Agama RI, 2007.

Rahman, Fazlur. Islam, terj. Ahsin Muhammad. Bandung: Pustaka, Cet. Ke-3, 1997.

Sabda, Syaifudin. "Pembaharuan Kurikulum Pendidikan Islam: Model Kurikulum Pendidikan Terpadu", Jurnal Khazanah, Vol. 1, No. 2, 2002.

Syahrodi, Jamali dkk. Membedah Nalar Pendidikan Islam: Pengantar Kearah Ilmu Pendidikan Islam. Yogyakarta: Pustaka Rihlah, 2001. 
'Ubûd, Abd al-Ghâni. Fî al-Tarbîyah al-Islâmîyah. Mesir: Dâr al-Fikr al'Arabî, 1977. 